\title{
Keefektifan Model Pembelajaran Relating, Experiencing, Applying, Cooperating, Transferring (REACT) untuk Meningkatkan Hasil Belajar Siswa SMP pada Materi Kalor
}

\author{
Okta Fakhruriza dan Ika Kartika \\ Pendidikan Fisika Fakultas Sains dan Teknologi Universitas Islam Negeri Sunan Kalijaga Yogyakarta \\ Jalan Marsda Adisucipto Yogyakarta 5528I \\ Surat-e: octhafahza@yahoo.com
}

\begin{abstract}
Tujuan penelitian ini untuk mengetahui: (I) Perbedaan hasil belajar kognitif dan afektif antara siswa yang mengikuti model pembelajaran REACT dengan siswa yang mengikuti model pembelajaran direc instruction (2) Keefektifan model pembelajaran REACT (3) Hasil belajar afektif siswa yang mengikuti model pembelajaran REACT.

Teknik analisis data dengan uji $t$, uji Mann Whitney-Udan normalized gain( $N$-Gain). Analisis lembar observasi dengan klasifikasi afektif. Hasil penelitian: (I) Tidak terdapat perbedaan hasil belajar kognitif antara siswa yang mengikuti model pembelajaran REACT dengan siswa yang mengikuti pembelajaran direc instructiondengan nilai sig. 0,09I. Terdapat perbedaan hasil belajar afektif antara siswa yang mengikuti model pembelajaran REACT dengan siswa yang mengikuti pembelajaran direc instructiondengan nilai sig.0,04 (2) Model pembelajaran REACT efektif untuk meningkatkan hasil belajar kognitif dengan $N$-gain kelas eksperimen 0,365 lebih besar dari $N$-gain kelas kontrol 0,317, hasil uji Effect size 0,4I (perbedaan peningkatan signifikan) (3) Hasil belajar afektif dengan rata-rata skor 3,49 dengan klasifikasi sangat baik.
\end{abstract}

Kata kunci: REACT, Hasil Belajar

\section{Pendahuluan}

Dalam proses pembelajaran agar lebih bermakna diperlukan model pembelajaran yang dapat mempermudah siswa dalam memahami materi-materi pelajaran. Salah satunya dengan model pembelajaran REACT yang merupakan pembelajaran kontekstual. Model pembelajran REACT yang terdiri dari lima tahapan; relating (mengaitkan), experiencing (mengalami), applying (menerapkan), cooperating (bekerja sama), transferring (mentransfer)[I]. Dimana dalam model pembelajaran REACT menekankan pada pemberian informasi yang berkaitan dengan informasi yang sebelumnya telah diketahuai oleh siswa, sehingga siswa akan lebih mudah memahami konsep-konsep yang disampaikan oleh guru karena sering dijumpai dalam kehidupan sehari-hari. Penerapan model pembelajaran REACT diharapkan dapat memberikan nuansa baru dalam proses pembelajaran materi kalor.

Berdasarkan hasil wawancara yang dilakukan terhadap guru mata pelajaran IPA kelas VII bahwa siswa masih kesulitan dalam memahami materi yang berhubungan dengan persamaan, guru memberikan persamaan dan memberikan contoh soal. Pembelajaran hanya berkisar pada pemberian materi oleh guru kemudian dicatat oleh siswa kemudian siswa mengerjakan soal. Dari pembelajaran tersebut menurut guru siswa belum bisa ketika diberi permasalahan yang lain misalnya untuk mencari variabel yang lain selain yang sudah dicontohkan oleh guru, siswa akan merasa kesulitan untuk menyelesaikannya. Dari hal tersebut siswa cenderung menghafalkan rumus dan menghafalkan konsep yang kemudian digunakan untuk menyelesaikan soal, sehingga untuk konsep materi yang sesungguhnya kurang dipahami.

Siswa belum berperan aktif dalam pembelajaran sehingga siswa hanya menerima konsep dari guru siswa belum menemukan konsep materi itu sendiri. Keadaan pembelajaran seperti ini kurang melatih siswa dalam memahami konsep materi sehingga berpengaruh pada rendahnya hasil belajar. Salah satu cara untuk memberikan pemahaman kepada siswa diperlukan adanya cara belajar yang disusun oleh guru yaitu model pembelajaran yang dapat memberikan pemahaman kepada siswa, bahwa pengetahuan yang didapatkan dari proses pembelajaran berhubungan dengan kehidupan sehari-hari. Dengan adanya bekal pengetahuan yang sudah diketahui siswa, akan mempermudah informasi baru yang didapatkan 
siswa dengan mengkaitkannya dengan pengetahuan yang sudah siswa dapatkan dalam kehidupan nyata.

Penelitian ini bertujuan untuk :

I. Mengetahui perbedaan hasil belajar kognitif dan afektif antara siswa yang mengikuti model pembelajaran REACT dengan siswa yang mengikuti model pembelajaran direct instruction.

2. Mengetahui keefektifan model pembelajaran REACT untuk meningkatkan hasil belajar kognitif siswa.

3. Mengetahui hasil belajar afektif siswa yang mengikuti model pembelajaran REACT.

\section{Kajian Pustaka}

Penelitian yang dilakukan oleh Ahmet Zeki, dengan menggunakan tiga strategi yaitu: REACT, Content-Based Instruction, dan Computer-Assisted Teaching, menyimpulkan bahwa ketiga strategi tersebut efektif untuk meningkatkan prestasi akademik, minat, dan sikap positif siswa dalam pembelajaran fisika[2].

Penelitian yang dilakukan oleh Kaselin, dkk, memperoleh hasil bahwa kemampuan komunikasi matematis siswa antara kelas eksperimen yang menggunakan pembelajaran dengan strategi REACT berbasis etnomatematika lebih baik dibandingkan kelas kontrol model ekspositori dan banyak siswa yang tuntas KKM[3].

Penelitian lain yang dilakukan oleh Muhammad Arifin mengenai keefektifan model pembelajaran REACT dan ARCS terhadap peningkatan motivasi belajar dan kemampuan pemecahan masalah matematika, memperoleh hasil, (I) model pembelajaran REACT tidak lebih efektif terhadap peningkatan motivasi belajar matematika siswa dibandingkan model pembelajaran ekspositori. (2) model pembelajaran REACT lebih efektif terhadap peningkatan kemampuan pemecahan masalah matematika siswa dibandingkan model pembelajaran ekspositori. (3) model pembelajaran REACT tidak lebih efektif terhadap peningkatan motivasi belajar matematika siswa dibandingkan model pembelajaran ARCS. (4) model pembelajaran REACT tidak lebih efektif terhadap kamampuan pemecahan masalah matematika siswa dibandingkan model pembelajaran ARCS[4].

\section{Metode Penelitian/Eksperimen}

Penelitian ini merupakan penelitian eksperimen semu (Quasi Experiment) dengan metode Pretest-Postest Control Group Design. Bentuk desain eksperimen ini merupakan pengembangan dari true experimental design, yang sulit dilaksanakan. Pretest-Posttest control group design merupakan metode penelitian yang mempunyai dua kelompok yang dipilih secara random, kemudian diberi pretest. Hasil pretest yang baik bila nilai kelompok eksperimen tidak berbeda secara signifikan.

Desain penelitian tersebut ialah diberikan pretest pada kelas kontrol dan kelas eksperimen. Kemudian untuk kelas eksperimen diberi perlakuan model pembelajaran REACT sadangkan untuk kelas kontrol mendapatkan pembelajaran Direct Introduction sesuai dengan RPP guru di sekolah. Setelah diberi perlakuan kelas eksperimen dan kelas kontrol diberikan posttest.

Teknik pengumpulan data yang digunakan adalah tes dan observasi. Serta instrumen dan digunakan dalam peneltian ini adalah soal pretest-posstets, lembar obsevasi, silabus, RPP dan Lembar Kerja Siswa. Teknik analisis instrumen dengan Validitas logis oleh ahli(judgment experts) dan validitas empiris dengan korelasi product moment, dan reliabilitas. Teknik yang digunakan untuk analisis butir soal dengan menggunakan korelasi product moment dengan angka kasar.

Untuk analisis data kognitif didahului dengan analisis prasyarat yaitu uji normalitas dan uji homogenitas. Uji normalitas dilakukan untuk mengetahui apakah data yang dimiliki oleh sampel terdistribusi normal atau tidak. Uji homogenitas dilakukan untuk mengetahui apakah populasi mempunyai variansi yang homogen atau tidak. Setelah melakukan uji prasyarat dilakukan uji hipotesis yaitu dengan uji Mann-Whitney-U. uji Mann-Whitney$U$ yang merupakan statistik nonparametrik. Uji statistik nonparametrik digunakan jika asumsi tertentu tidak terpenuhi (data tidak terdistribusi normal). Uji dua pihak digunakan untuk mengetahui ada atau tidaknya perbedaan hasil belajar kognitif siswa antara kelas eksperimen dan kelas kontrol. sedangkan untuk mengetahui ada perbedaan atau tidak pada hasil belajar afektif di uji dengan uji $t$. Sebelum data afektif dianalisis dengan uji $t$ data afektif dirubah dari data ordinal menjadi data interval dengan bantuan program MSI.

Untuk mengetahui peningkatan hasil belajar siswa diuji dengan persamaan $N$-gain. Persamaan $N$-gain

$$
\mathrm{N}_{\text {gain }}=\frac{\text { skor posttes }- \text { skor pretest }}{\text { skor ideal }- \text { skor pretest }}
$$

dengan klasifikasi $N$-gain

Tabel I. Tafsiran Keefektifan Dari Nilai N-Gain

\begin{tabular}{cc}
\hline Rata-rata N-Gain Ternormalisasi & Klasifikasi \\
\hline $0,70<\mathrm{N}$-Gain $\leq \mathrm{I}, 00$ & Tinggi \\
$0,30<\mathrm{N}$-Gain $\leq 0,70$ & Sedang \\
$\mathrm{N}-$ Gain $\leq 0,30$ & Rendah \\
\hline
\end{tabular}

Jika sudah diketahui hasilnya, maka dapat ditarik kesimpulan kriteria tingkat keefektifan masing-masing 
kelas sebagai hasil dari pengolahan data. Model pembelajaran dikatakan efektif jika klasifikasi $N$-gain dalam klasifikasi sedang atau tinggi ( $N$-gain signifikan).

Untuk mengetahui seberapa efektif perlakuan yang dilakukan dalam meningkatkan hasil belajar kognitif dapat diketahui melalui ukuran efek atau effect size. persamaan yang digunakan adalah sebagai berikut

$$
d=\frac{M_{1}-M_{2}}{\sqrt{\frac{S_{1}^{2}+S_{2}^{2}}{2}}}
$$

$$
\begin{array}{cl}
\underset{d}{\text { dengan }} & =\text { Nilai Effect Size } \\
M_{1} & =\text { Rata-rata skor N-gain eksperimen } \\
M_{2} & =\text { Rata-rata } N \text {-gain kontrol } \\
S_{1}^{2} & =\text { Varians kelas eksperimen } \\
S_{2}^{2} & =\text { Varians kelas kontrol }
\end{array}
$$

Varians kelas eksperimen dan kelas kontrol dapat dihitung dengan persamaan berikut.

$$
S^{2}=\frac{\sum(x i-\bar{x})}{(n-1)}
$$

Kriteria yang diusulkan Cohen dalam Dali S. Naga besar kecilnya ukuran efek adalah sebagai berikut.

Tabel 2. Kategori Effect Size

\begin{tabular}{cc}
\hline Nilai $d$ & Kategori \\
\hline $0<\mathrm{d} \mathrm{0,2}$ & Efek kecil \\
$0,2<\mathrm{d}<0,8$ & Efek sedang \\
$\mathrm{d}>0,8$ & Efek besar \\
\hline
\end{tabular}

\section{Hasil Penelitian dan Pembahasan}

Perbandingan hasil observasi kelas eksperimen dan kelas kontrol.

Tabel 3. Perbandingan Klasifikasi Afektif

\begin{tabular}{ccc}
\hline Kelas & Rata-rata Skor & Klasifikasi \\
\hline Eksperimen & 3,49 & Sangat Baik \\
Kontrol & 3,06 & Baik \\
\hline
\end{tabular}

terlihat bahwa antusias sikap siswa dalam mengikuti model pembelajaran REACT di kelas eksperimen dalam klasifikasi sangat baik dengan skor 3,49. Sedangkan di kelas kontrol dalam klasifikasi baik dengan skor 3,06. Jadi dapat disimpulkan hasil pembelajaran afektif di kelas ekspermen lebih baik dari kelas kontrol.

Perbedaan hasil belajar ranah afektif pada siswa kelas eksperimen dan kelas kontrol dilihat dari skor pada lembar observasi yang sudah diubah menjadi data interval. Skor konversi tersebut diuji secara statistik dengan uji $t$ dua pihak. Ada perbedaan atau tidak ada perbedaan ratarata skor afektif kelas eksperimen dan kelas kontrol dilihat dari nilai Sig.(2-tailed) yang dibandingkan dengan taraf signifikansi $\alpha$ yaitu 0,05 .

Dari perhitungan uji $t$ nilai Sig.(2-tailed) sebesar 0,04I yang berarti lebih kecil dari taraf signifikansi. Maka dapat disimpulkan bahwa terdapat perbedaan hasil belajar ranah afektif antara kelas eksperimen dan kelas kontrol.

Skor pretest yang diperoleh digunakan untuk mengetahui kemampuan awal siswa sebelum diberi treatment. Skor pretest dianalisis menggunakan uji MannWhitney- $U$ Adapun hasil analisa de ngan nilai Asymp.Sig.(2-tailed) sebesar 0,09I yang berarti lebih besar dari pada taraf signifikansi $\alpha .(0,05)$ Maka dapat diketahui bahwa kemampuan awal siswa kelas eksperimen dan kelas kontrol tidak berbeda.

Skor posttest tersebut diuji secara statistik dengan uji Mann-Whitney- $U$. Ada perbedaan atau tidak ada perbedaan rata-rata skor posttest kelas eksperimen dan kelas kontrol dilihat dari nilai Asymp.Sig.(2-tailed) sebesar 0,152 yang berarti lebih besar dari taraf signifikansi (0,05). Maka dapat disimpulkan bahwa tidak terdapat perbedaan hasil belajar ranah kognitif antara kelas eksperimen dan kelas kontrol.

Peningkatan hasil belajar ranah kognitif siswa dilihat dari hasil uji $N$-gain skor pretest dan posttest antara kelas eksperimen dan kelas kontrol. Hasil tersebut disajikan dalam Tabel

Tabel 4. $N$-gain Kelas Eksperimen dan Kelas Kontrol

\begin{tabular}{llllll}
\hline \multicolumn{1}{c}{ Kelas } & N & $\begin{array}{c}\text { Rata } \\
\text { Posttest }\end{array}$ & $\begin{array}{c}\text { Rata } \\
\text { Pretest }\end{array}$ & $\begin{array}{c}N- \\
\text { gain }\end{array}$ & Klasifikasi \\
Eksperimen & 34 & I I,88 & 7,47 & 0,365 & Sedang \\
Kontrol & 35 & I0,4 & $7, \mathrm{I} 4$ & 0,317 & Sedang \\
\hline
\end{tabular}

Untuk mengetahui seberapa besar keefektifan yang diberikan dalam meningkatkan hasil belajar kognitif dapat dilihat dari Effect Size. Data yang digunakan adalah $N$ gain kelas eksperimen dan kelas kontrol.

Tabel 5. Hasil Effect Size

\begin{tabular}{ccccc} 
Kelas & $\begin{array}{c}\text { Rata-rata } N \text { - } \\
\text { gain }(\mathbf{M})\end{array}$ & $\begin{array}{c}\text { Varians } \\
\text { kelas }\end{array}$ & $\begin{array}{c}\text { Effect } \\
\text { Size }\end{array}$ & Ket \\
\hline Eksperimen & 0,36 & 0,12 & $0,4 \mathrm{I}$ & $\begin{array}{c}\text { Effect } \\
\text { sedang }\end{array}$ \\
Kontrol & $0,3 \mathrm{I}$ & 0,10 & & \\
\hline
\end{tabular}

Artinya bahwa penerapan model pembelajaran REACT untuk meningkatkan hasil belajar efektif digunakan dengan ukuran efek sedang. 


\section{Kesimpulan}

I. Tidak terdapat perbedaan hasil belajar kongnitif antara siswa yang mengikuti model pembelajaran REACT dengan siswa yang mengikuti model pembelajaran direct instruction. Terdapat perbedaan hasil belajar afektif antara siswa yang mengikuti model pembelajaran REACT dengan siswa yang mengikuti model pembelajaran direc instruction.

2. Model pembelajaran Relating, Experiencing, Applying, Cooperating, Transferring (REACT) efektif untuk meningkatkan hasil belajar ranah kognitif dengan hasil $N$-gain kelas eksperimen 0,365 lebih tinggi dari kelas kontrol 0,317. Effect Size $0,4 \mathrm{I}$ (peningkatan signifikan)

3. Hasil belajar afektif untuk setiap aspek afektif, aspek senang terhadap guru dan mapel yang diberikan dengan skor 3,59 dengan klasifikasi afektif sangat baik, aspek perhatian siswa terhadap materi yang dijelaskan oleh guru dengan skor 3,43 dengan klasifikasi afektif sangat baik, aspek sikap siswa saat teman menyampaikan pendapat dengan skor 3,26 dengan klasifikasi afektif sangat baik, aspek sikap siswa dalam diskusi kelompok dengan skor 3,67 dengan klasifikasi afektif sangat baik. Dengan ratarata skor dari semua aspek adalah 3,49 dengan klasifikasi afektif sangat baik.

\section{Ucapan Terimakasih}

Terimakasih kepada Ibu Ika Kartika yang telah membimbing dalam penelitian ini, sehingga peneltian ini dapat terselesaikan dengan baik.

\section{Kepustakaan}

[I] Kokom Komalasari. (2010). Pembelajaran Kontekstual Konsep dan Aplikasi. Bandung: Refika Aditama.

[2] Zeki, Ahmet. (20II). Investigation of Student Centered Teaching Application of Physics Student Teacher. Eurasian Journal of Physics and Chemistry Education Jan 5I-58.

[3] Kaselin, dkk. (2012). Kemampuan Komunikasi Matematis pada Pembelajaran Matematika Dengan Strategi REACT Berbaasis Etnomatematika. Unnes Journal of Mathematics Education Research,

[4] Arifin, Muhammad. (2014). Efektivitas Model Pembelajaran REACT dan ARCS terhadap Peningkatan Motivasi Belajar dan Kemampuan Pemecahan Masalah Matematika. Yogyakarta: UIN Sunan Kalijaga. 